\title{
CHANGES OF FLUORIDE CONTENT IN THE SAND FROM SANDBOXES LOCATED ON CHILDREN PLAYGROUNDS IN POLICE (WEST POMERANIA, POLAND)
}

\author{
Arkadiusz Telesiński' ${ }^{1}$ Magdalena Czałczyńska-Podolska², Łukasz Węgrzynowski' \\ Robert Biczak³ ${ }^{3}$ Natalia Telesińska ${ }^{4}$
}

1 Department of Plant Physiology and Biochemistry, West Pomeranian University of Technology in Szczecin, Słowackiego 17, 71-434 Szczecin, Poland

2 Department of Contemporary Architecture, Theory and Methodology of Design, West Pomeranian University of Technology in Szczecin, Żołnierska 50, 71-210 Szczecin, Poland

${ }^{3}$ Department of Biochemistry and Ecotoxicology, Jan Długosz University in Częstochowa, Armii Krajowej 13/15, 42-200 Częstochowa, Poland

${ }^{4}$ Faculty of Building Services, Hydro and Environmental Engineering, Warsaw University of Technology, Nowoursynowska 20, 00-653 Warsaw, Poland

* Corresponding author's e-mail: arkadiusz.telesinski@zut.edu.pl

Received: 2017.06 .18 Accepted: 2017.08.01 Published: 2017.09 .01

\begin{abstract}
The aim of the study was to determine the fluoride content in the sand from sandboxes in Police town (West Pomerania, Poland). This area is exposed to excessive emissions of fluoride compounds because of the proximity of chemical plants. The sand samples were collected five times in the period from March to November in 2016. The fluoride content was determined using the potentiometric method with an ion-selective fluoride electrode. The obtained results showed that the fluoride content ranged from 0.09 to $1.48 \mathrm{mg} \cdot \mathrm{kg}^{-1} \mathrm{dm}$. The lowest fluoride content was recorded in the sand collected in the place, which was the closest to the emitter, and the highest one in the samples from sandbox, which was the furthest from the emitter. Analyzing the changes in the content of this element over time, the largest fluoride concentration of sand occurred in July or September depending on the location. Pearson correlation coefficient at $\mathrm{p}<0.05(\mathrm{r}=0.925)$ showed a significant positive correlation between the fluoride content and the distance from fluoride emitter.
\end{abstract}

Keywords: distance from emitter, fluoride, risk assessment, sandboxes

\section{INTRODUCTION}

Since the mid-nineteenth century, children's playgrounds have been present in human history. In the meantime they have undergone many transformations (Czałczyńska-Podolska 2014). Empty open spaces were quickly filled up with various types of play elements. In Poland, sandboxes are one of the integral elements of playgrounds (Kasprzak and Raszka 2008). Sandboxes allow children to shape their imagination and experience cooperative learning (Czałczyńska-
Podolska 2016). It is very important that sandboxes for children should be safe.

Children consitute a population group often referred to as group of special risk because they often put dirty hands or toys in their mouths, posing the risk of swallowing many toxic substances (Oliver 1997). In addition, children playing in sandboxes remain exposed to the inhalation of dust particles that contain a number of contaminants (Nieć et al. 2013).

Fluoride is one of the most controversial elements because of its extremely diverse effects on 
organisms. For some organisms, it is classified in the group of essential micronutrients and for others only as a highly toxic xenobiotic (Telesiński and Śnioszek 2009). Fluoride affects humans in both positive and, more commonly, negative ways, due to the small margin between a safe and toxic dose of this anion (Palczewska-Komsa et al. 2016). According to Ekstrand et al. (1994), 80\% of the fluoride consumed is necessary for growing bones and teeth in children. However, the mechanisms through which fluorides cause toxic effects are numerous and varied. These mechanisms include the primary effect on the activity of many enzymes, and thus the functioning of the entire metabolic pathway (glycolysis, Krebs cycle, and cellular respiration), gene expression, secretion, and transport processes. Many reports have focused on the study of disorders related to the cell cycle, cell proliferation and migration, as well as the processes of apoptosis and necrosis (Sun et al. 2016). One of the best known and most widely discussed mechanisms of fluoride toxicity is their participation in the generation of reactive oxygen species and the impairment of the functioning of the antioxidant barrier (Chlubek 2003).

Police, located in the West Pomeranian District in Poland, is exposed to excessive emissions of fluoride compounds because of the proximity of chemical plants. Therefore, the aim of the study was to assess the changes of fluoride contents in the sand from sandboxes located in Police, according to the distance from the emitter and term of samples collection.

\section{MATERIALS AND METHODS}

Approximately 14 sandboxes located in the Police town were covered in this study. The sand samples were collected five times at two-month intervals from March to November in 2016. The distance of the sandboxes from the emitter of fluoride compounds ranged from 3.61 to 4.55 $\mathrm{km}$. Table 1 shows detailed information about the distance from the emitter. All sandboxes or playgrounds were fenced, except for point 4.

The sand samples were in dried to air-dried state. Fluoride was extracted from samples with $2 \mathrm{M} \mathrm{HClO}_{4}$ at the temperature of $70^{\circ} \mathrm{C}$. Determinations of fluoride were made by means of the potentiometric method with an ion-selective fluoride electrode made by ORION 920A (Thermo Scientific). The determinations followed the protocol devised by Nowak and Kuran (2000), with the buffering solution TISAB III.

The fluoride content determination was performed in three replicates for each term, and the significance of the observed differences was verified using a one-way analysis of variance followed by the post-hoc Tukey's HSD test. The differences with a $p$ value of $<0.05$ were considered as significant. The correlation coefficient between the fluoride content and distance from fluoride emitter were interpreted as ordinary correlation coefficients. All statistical analyses were carried out using the Statistica 12.5 software.

\section{RESULTS AND DISCUSSION}

The fluoride content in the sand, taken from the sandboxes located in Police town, ranged from 0.09 to $1.48 \mathrm{mg} \cdot \mathrm{kg}^{-1} \mathrm{dm}$. The lowest fluoride content was recorded in the sand collected in the place which is closest to the emitter (\# 1) in May and the largest in the sample sandbox furthest from the emitter (\# 14) in July. The obtained amounts, compared to similar studies with soil samples, are relatively low (Telesiński et al. 2010, Krzywy et al. 2013, Hong et al. 2016). This is mainly due to the presence of organic matter in the soil as well as the formation of aluminum and calcium complexes (Turner et al. 2005, Romar et al. 2009). Saeki (2008) reported that fluo-

Table 1. Distance of sandboxes from the fluoride emitter

\begin{tabular}{|c|c|c|c|}
\hline Number of location & Distance from F emitter $(\mathrm{km})$ & Number of location & Distance from F emitter $(\mathrm{km})$ \\
\hline$\# 1$ & 3.61 & $\# 8$ & 4.22 \\
\hline$\# 2$ & 3.80 & $\# 9$ & 4.30 \\
\hline$\# 3$ & 3.82 & $\# 10$ & 4.31 \\
\hline$\# 4$ & 3.91 & $\# 11$ & 4.32 \\
\hline$\# 5$ & 4.11 & $\# 12$ & 4.47 \\
\hline$\# 6$ & 4.15 & $\# 13$ & 4.49 \\
\hline 7 & 4.19 & $\# 14$ & 4.55 \\
\hline
\end{tabular}


ride and other ions in the soil solution are usually hydrated. Since the electrostatic forces must act through this water coating, these ions are often weak. Equally charged ions can therefore compete for the charged sites, which are consequently called exchange sites. The fluorine content depends on the direction of distance from the emitter. Krzywy et al. (2013) showed that the highest fluoride content in the soil was northwest from the emitter. However, all sandboxes studied in this research are located in the southwest. Moreover, such low fluoride content may result from the fact that within the last twenty years, the emission level of this anion from the emitter at Police has clearly decreased (Stogiera and Buczkowska-Radlińska 2014).

While analyzing the changes in the content of this element over time, the largest fluoride concentration of sand occurred in July or September depending on the location (Table 2). The comparison of the mean fluoride content in the sand collected from all sandbox locations at the sampling dates indicated that it was the largest in July (Figure 1). However, Krzywy et al. (2013) reported that the fluoride content in the soil samples taken around this anion emitter contained on average more of fluoride during the spring than in autumn, whereas Telesiński et al. (2010) showed that in the forest soils around the chemical plants the highest fluoride content was found in the samples collected in June. This discrepancy may have resulted from both the wind direction (General et al. 2013) and a likely replacement of sand in sandboxes (Nieć et al. 2013).
Pearson correlation coefficient at $p<0.05$ $(\mathrm{r}=0.925)$ showed a significant positive correlation between the fluoride content and the distance from the fluoride emitter (Figure 2). This shows the increase in the fluoride content occurring along with the distance from the emitter. This is a proof obtained in the research on soil and plant samples carried out by many authors (Franzaring et al. 2006, Jha et al. 2008, Telesiński et al. 2010, Koblar et al. 2011, Krzywy et al. 2013). The obtained results still indicate on a slight fluoride contamination of the sand, despite the proximity of the sandboxes to this anion emitter. However, due to the frequent children presence, continuous exposure to fluoride can lead to fluorosis of the teeth and the skeleton (Vierra et al. 2005). Fluorides can also inhibit the activity of certain enzymes as well as affect the bioenergetic processes and tissue respiration (Stogiera and Buczkowska-Radlińska 2014). Moreover, the sand in sandboxes and soils in playground areas may be contaminated with heavy metals (Nieć et al. 2013), pathogenic microorganisms (Błaszak and Zatoń 2015), and parasite eggs (Błaszkowska et al. 2013, Brochocka et al. 2014, Moskvina et al. 2016).

\section{CONCLUSION}

The fluoride content in the sand from the sandboxes located in Police town ranged from 0.09 to $1.48 \mathrm{mg} \cdot \mathrm{kg}^{-1} \mathrm{dm}$. First, the lowest fluoride content was recorded in the sand collected

Table 2. Fluoride contents $\left(\mathrm{mg} \cdot \mathrm{kg}^{-1} \mathrm{dm}\right)$ in sand from sandboxes located on playgrounds in Police (data are expressed as a mean $\pm \mathrm{SD}$ of three replicates)

\begin{tabular}{|c|c|c|c|c|c|}
\hline $\begin{array}{c}\text { Number of } \\
\text { sandbox location }\end{array}$ & March & May & July & September & November \\
\hline 1 & $0.11 \pm 0.04 \mathrm{~g}$ & $0.09 \pm 0.02^{h}$ & $0.26 \pm 0.04^{h}$ & $0.33 \pm 0.06^{e}$ & $0.18 \pm 0.06^{9}$ \\
\hline 2 & $0.23 \pm 0.06 \mathrm{fg}$ & $0.29 \pm 0.07 \mathrm{~g}$ & $0.38 \pm 0.05^{g}$ & $0.28 \pm 0.01^{\mathrm{e}}$ & $0.25 \pm 0.04$ fg \\
\hline 3 & $0.24 \pm 0.07 \mathrm{fg}$ & $0.27 \pm 0.03 \mathrm{~g}$ & $0.41 \pm 0.08 \mathrm{~g}$ & $0.35 \pm 0.05^{e}$ & $0.33 \pm 0.07^{f}$ \\
\hline 4 & $0.34 \pm 0,03^{f}$ & $0.38 \pm 0.06^{g}$ & $0.45 \pm 0.10^{g}$ & $0.29 \pm 0.05^{\mathrm{e}}$ & $0.28 \pm 0.03^{f g}$ \\
\hline 5 & $0.72 \pm 0.11^{\mathrm{cd}}$ & $0.71 \pm 0.06$ ef $^{-1}$ & $0.80 \pm 0.06^{\mathrm{e}}$ & $0.55 \pm 0.08^{d}$ & $0.63 \pm 0.09^{d}$ \\
\hline 6 & $0.84 \pm 0.12^{c}$ & $0.82 \pm 0.02^{\mathrm{e}}$ & $0.99 \pm 0.11^{d}$ & $0.73 \pm 0.09^{c}$ & $0.69 \pm 0.06^{d}$ \\
\hline 7 & $0.64 \pm 0.10 \mathrm{de}$ & $0.69 \pm 0.11^{f}$ & $0.83 \pm 0.13^{e}$ & $0.62 \pm 0.04^{c d}$ & $0.59 \pm 0.05$ de \\
\hline 8 & $0.51 \pm 0.14^{\mathrm{e}}$ & $0.62 \pm 0.08^{f}$ & $0.69 \pm 0.05^{f}$ & $0.68 \pm 0.10^{\mathrm{cd}}$ & $0.49 \pm 0.09^{\mathrm{e}}$ \\
\hline 9 & $0.98 \pm 0.15^{b}$ & $0.95 \pm 0.09 d$ & $1.21 \pm 0.09^{c}$ & $1.23 \pm 0.11^{b}$ & $0.94 \pm 0.07^{c}$ \\
\hline 10 & $1.04 \pm 0.07^{b}$ & $1.21 \pm 0.11^{b}$ & $1.22 \pm 0.08^{c}$ & $1.32 \pm 0.02^{\mathrm{ab}}$ & $0.94 \pm 0.04^{c}$ \\
\hline 11 & $0.95 \pm 0.07 \mathrm{bc}$ & $1.33 \pm 0.12^{a}$ & $1.28 \pm 0.08^{b c}$ & $1.22 \pm 0.06^{b}$ & $1.03 \pm 0.09^{c}$ \\
\hline 12 & $1.21 \pm 0.11^{\mathrm{a}}$ & $1.32 \pm 0.09 a b$ & $1.33 \pm 0.12^{b}$ & $1.45 \pm 0.09^{a}$ & $1.19 \pm 0.11^{\mathrm{b}}$ \\
\hline 13 & $1.04 \pm 0.09^{b}$ & $1.20 \pm 0.11 \mathrm{bc}$ & $1.42 \pm 0.21 \mathrm{ab}$ & $1.34 \pm 0.12^{\mathrm{ab}}$ & $1.33 \pm 0.12^{a}$ \\
\hline 14 & $1.33 \pm 0.13^{a}$ & $1.12 \pm 0.22^{c}$ & $1.48 \pm 0.17^{a}$ & $1.38 \pm 0.13 \mathrm{ab}$ & $1.21 \pm 0.09^{b}$ \\
\hline
\end{tabular}

Different letters in each column correspond to significant differences (Tukey-HSD test, $p<0.05$ ). 


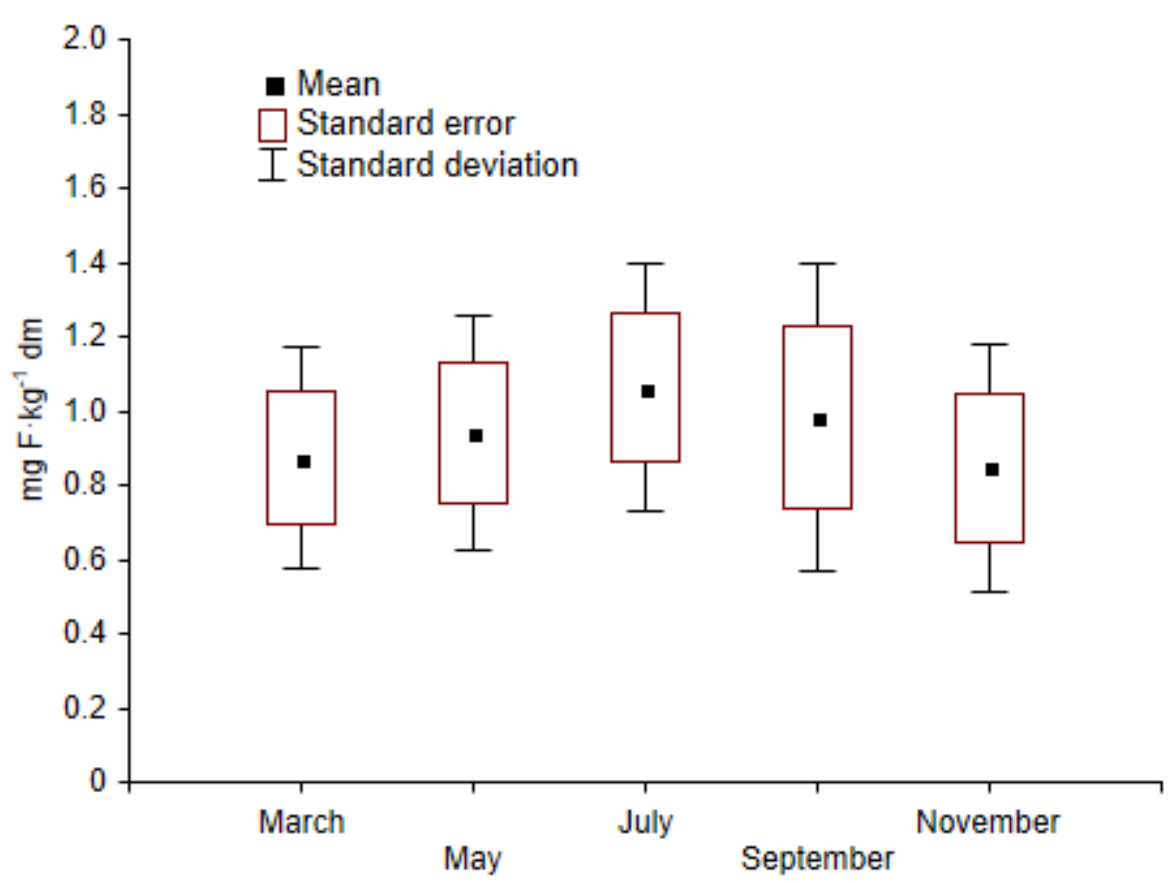

Figure 1. Mean fluoride content in the sand from the sandboxes according to the term of samples collection

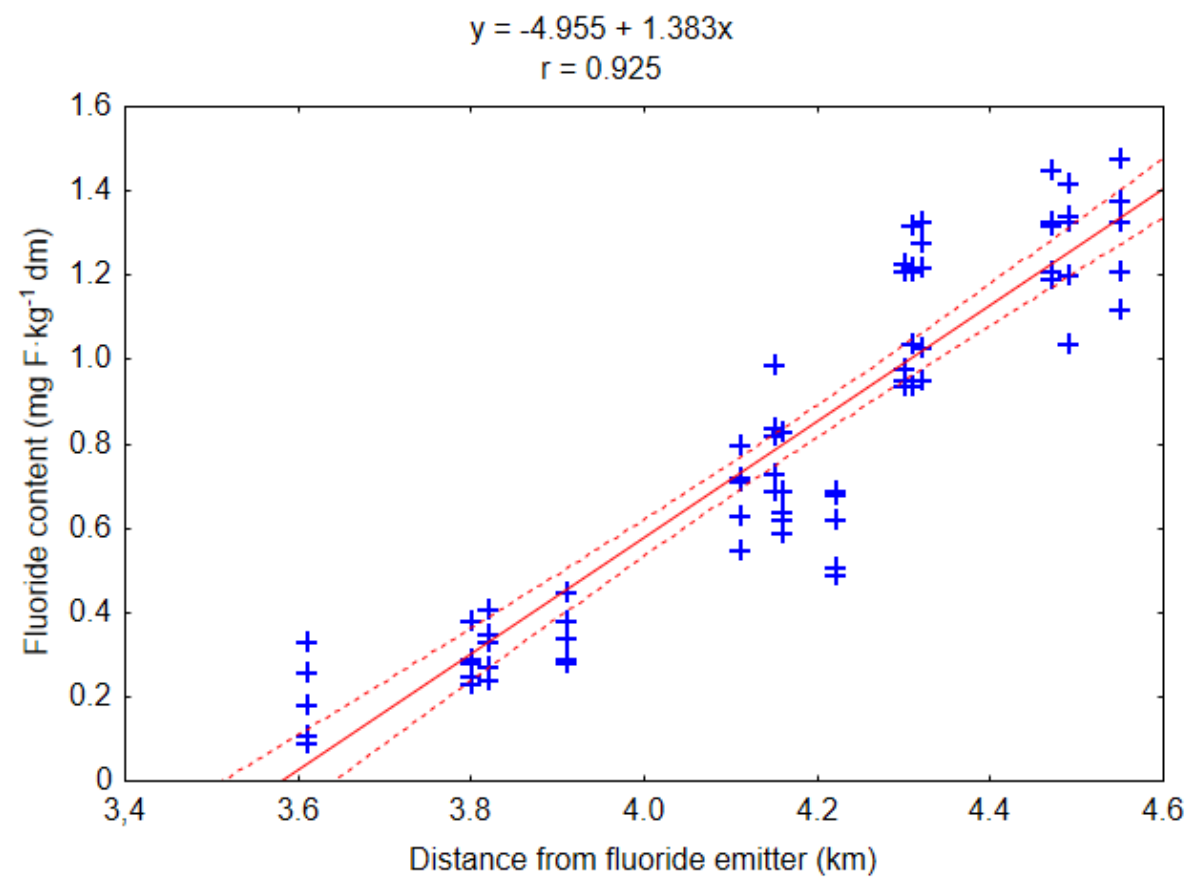

Figure 2. Pearson linear correlation between fluoride content in the sand and the sandbox distance from the fluoride emitter

in the place, which was the closest to the emitter, and the largest in the samples from sandbox, which was the furthest from the emitter. Second, the largest fluoride concentration of sand occurred in July or September, depending on the location. Third, Pearson correlation coefficient at $p<0.05(\mathrm{r}=0.925)$ showed a significant positive correlation between the fluoride content and the distance from fthe luoride emitter. However, the obtained results still indicate a slight fluoride contamination of the sand, despite the proximity of the sandboxes to this anion emitter. 


\section{REFERENCES}

1. Błaszak M., Zatoń K. 2015. Effectiveness of the sandpits security system against microorganisms and intestinal parasites sand contamination. J. Ecol. Eng. 16, 4, 215-223.

2. Błaszkowska J., Wójcik A., Kurnatowski P., Szwabe K. 2013. Geohelminth egg contamination of children's play areas in the city of Lodz (Poland). Wet. Parasitol. 192, 1-3, 228-233.

3. Brochocka A., Barczak T., Kasprzak J., Lewińska J. 2014. Assessment of environmental contamination of selected urban areas with eggs of helminths of the Toxocara spp. genus in Kuyavian-Pomeranian voivodeship in 2010-2011 [in Polish]. Probl. Hig. Epidemiol. 95, 3, 630-635.

4. Chlubek D. 2003. Fluoride and oxidative stress. Fluoride 36, 217-228.

5. Czałczyńska-Podolska M. 2014. The impact of playground spatial features on children's play and activity forms: An evaluation of contemporary playgrounds' play and social value. J. Environ. Psychol. 38, 132-142.

6. Czałczyńska-Podolska M. 2016. Contemporary playground as attractive space. Przestrzeń i Forma $26,27-38$.

7. Ekstrand J., Ziegler E.E., Nelson S.E., Forman S.J. 1994. Absorption and retention of dietary and supplemental fluoride by infants. Adv. Dent. Res. 8, 175-180.

8. Franzaring J., Hrenn H., Schumm C., Klumpp A., Fangmeier A. 2006. Environmental monitoring of fluoride emissions using precipitation, dust, plant and soil samples. Environ. Pollut. 144, 1, 158-165.

9. Hong B.D., Joo R.N., Lee K.S., Lee D.S., Rhie J.H., Min S., Song S.G., Chung D.Y. 2016. Fluoride in soil and plant. Kor. J. Agric. Sci. 43, 4, 522-536.

10. Jha S.K., Nayak A.K., Sharma Y.K., Mishra V.K., Sharma D.K. 2008. Fluoride accumulation in soil and vegetation in the vicinity of brick fields. Bull. Environ. Contam. Toxicol. 80, 4, 369-373.

11. Kasprzak K., Raszka B. 2008. Town playgrounds - historical presentation [in Polish]. Nauka Przyr. Technol. 2, 4, \#48.

12. Koblar A., Tavčar G., Ponikvar-Svet M. 2011. Effects of airborne fluoride on soil and vegetation. J. Fluor. Chem. 132, 10, 755-759.

13. Krzywy E., Ciubak J., Możdżer E., Telesiński A. 2013. Oddziaływanie emitorów Zakładów Chemicznych Fosfan SA w Szczecinie na zawartość fluoru w glebach i trawach [Impact of emitters from Fosfan Company Ltd. on fluorine content in soil and grasses]. Przem. Chem. 92/8, 1461-1463.

14. Moskvina T.V., Bartkova A.D., Ermolenko A.V. 2016. Geohelminths eggs contamination of sand- pits in Vladivostok, Russia. Asian Pac. J. Trop. Med. 9, 12, 1215-1217.

15. Nieć J., Baranowska R., Dziubanek G., Rogala D. 2013. Children's exposure to heavy metals in the soils of playgrounds, sports fields, sandpits and kindergarten grounds in the region of Upper Silesia [in Polish]. J. Ecol. Health 17, 2, 56-62.

16. Nowak J., Kuran B. 2000. Dynamics of fluoride transformation in soil from soluble to water insoluble forms [in Polish]. Rocz. Glebozn. 51, 1/2, 125-133.

17. Oliver M.A. 1997. Soil and human health: A review. Eur. J. Soil Sci. 48, 573-592.

18. Palczewska-Komsa M., Wilk A., Stogiera A., Chlubek D., Buczkowska-Radlińska J., Wiszniewska B. 2016. Animals in biomonitoring studies of environmental fluoride pollution. Fluoride 49, $3 \mathrm{Pt}$ 2, 279-292.

19. Romar A., Gago C., Fernández-Marcos M.L., Álvarez E. 2009. Influence of fluoride addition on the composition of solution equilibrium with acid soils. Pedosphere 19, 1, 60-70.

20. Saeki K. 2008. Adsorption sequence of toxic inorganic anions on a soil. Bull. Environ. Contam. Toxicol. 81, 508-512.

21. Stogiera A., Buczkowska-Radlińska J. 2014. Anthropogenic sources of fluorine - the impact on the environment and human health - a literature review [in Polish]. Dental Forum 42, 2, 57-62.

22. Sun Z., Zhang W., Xue X., Zhang Y., Niu R., Li X., Li B., Wang X., Wang J. 2016. Fluoride decreased the sperm ATP of mice through inhabiting mitochondrial respiration. Chemosphere 144, 1012-1017.

23. Telesiński A., Śnioszek M. 2009. Bioindicators of environmental pollution with fluorine [in Polish]. Bromat. Chem. Toksykol. 42, 4, 1148-1154.

24. Telesiński A., Smolik B., Grabczyńska E. 2010. Formation of adenylate Energy chargé (AEC) versus the fluorine content in forest soil in the area affected by emission from Police Chemical Plant. J. Elem. 15, 2, 355-362.

25. Turner B.D., Binning P., Stipp, S.L.S. 2005. Fluoride removal by calcite: Evidence for fluorite precipitation and surface adsorption. Environ. Sci. Technol. 39, 9561-9568.

26. Vierra A.P., Mousnych M., Maia R., Hancoch R., Everett E.T., Grynpas M.D. 2005. Assessment of teeth as biomarkers for skeletal fluoride exposure. Osteoporosis Int. 16, 1576-1582.

27. Walna B., Kurzyca I., Bednorz E., Kolendowicz L. 2013. Fluoride pollution of atmospheric precipitation and its relationship with air circulation and weather patterns (Wielkopolski National Park, Poland). Environ. Monit. Assess. 185, 7, 5497-5514. 